\title{
43. Seçme Hikâyeler Hacivat ve Karagöz eserinin İngilizce çevirisi üzerine bir çalışma
}

\section{Burcu YAMAN}

APA: Yaman, B. (2021). Seçme Hikâyeler Hacivat ve Karagöz eserinin İngilizce çevirisi üzerine bir çalışma. RumeliDE Dil ve Edebiyat Araştırmaları Dergisi, (Ö9), 552-574. DOI: 10.29000/rumelide.984847.

Öz

Geleneksel tiyatromuzun en güzel örneklerinden olan "Karagöz Gölge Oyunu” Türkiye'nin UNESCO somut olmayan kültürel miras listesinde yer alan kültürel zenginliklerinden biridir. Bu değerlerin gelecek kuşaklara aktarımı hem genç neslin bu değerleri tanıması hem de kültürlerarası diyaloğun ve etkileşimin sağlanması açısından büyük önem taşımaktadır. Bunun en etkili yollarından biri de yeni ürünlerin ortaya çıkartılması, çevirileri ve çevirilerinin sahnelenmesi yoluyla dünya dolaşımının sağlanmasıdır. Muhavere yazımı bu alanda yapılan en önemli çalışmalardan biridir. Fakat yazılan oyunların çevirilerinin çok az olması ve yabancı dilde çok az sayıda oyun sahnelenmesi kültürel ve kültürlerarası sürekliliğin sağlanmasını engelleyen faktörlerin başında gelmektedir. Bu bağlamda çevirmen ve çevirmen adaylarına önemli görevler düşmektedir. Karagözün yarattığı, mizah, eğlence ve gölge oyunu geleneğinin başka kültürlere en iyi şekilde aktarılması gerekmektedir. Bu çalışmada Profil yayıncılı̆ga ait Selected Stories of Hacivat and Karagöz adlı eser Katharina Reiss'ın çeviri eleştirisi yaklaşımı doğrultusunda kaynak metinle karşılaştırmalı olarak incelenmiştir. Yapılan inceleme neticesinde kültürel öğelerin aktarımın da zorluklar yaşandığı ve özellikle tekerleme, bilmece yapılarında yer alan mizahi etkinin hedef kültürde sağlanamadığı gözlemlenmiştir. Bu problemler için yaratıcı metin uyarlaması doğrultusunda öneriler sunulmuştur. Bu kapsamda yapılan çalışmalardan örnekler verilmiştir. Çalışmanın çevirmen ve çevirmen adaylarına, Karagöz gölge oyununun çevirilerine ve bu yolla sürekliliğinin ve dünya dolaşımının sağlanmasına ve kültürlerarası diyaloğa katkı sunacağı düşünülmüştür.

Anahtar kelimeler: Çeviri, Gölge Oyunu Karagöz, Katharina Reiss'ın çeviri eleştirisi yaklaşımı, yaratıcı metin uyarlaması

\section{A study on the English translation work Selected Stories of Hacivat and Karagöz}

\begin{abstract}
Karagöz shadow theatre is one of the cultural values placed in the list of Turkey's Intangible Cultural Heritage UNESCO. The transfer of these values to future generations is important both interms of introducing them to youngers and ensuring intercultural dialogue. One of the most effective way of this is to translate and stage these plays to provide their circulation. First step is rewriting conversations. But the number of these studies are few and also the translations and staging of the plays are few. This is one of the leading factor that prevents the cultural sustainability. Thus translators have some important tasks. The tradition of humour, amusement and shadow theatre should be transferred in the best way. In this study the work titled Selected Stories of Hacivat and Karagöz by Profil publishing has been analyzed through Katharina Reiss' criticism approach. The results showed that there were some difficulties in the transferring of the cultural elements and It was observed that the effect in the source
\end{abstract}

1 Öğr. Gör. Dr., Ondokuz Mayıs Üniversitesi, Yabancı Diller Yüksekokulu, (Samsun, Türkiye) burcuyaman1@gmail.com, ORCID ID: 0000-0001-6381-4122 [Araștırma makalesi, Makale kayıt tarihi: 25.07.2021-kabul tarihi: 20.08.2021; DOI: 10.29000/rumelide.984847]

Adres
RumeliDE Dil ve Edebiyat Araştırmaları Dergisi Osmanağa Mahallesi, Mürver Çiçeği Sokak, No:14/8 Kadıköy - ISTANBUL / TÜRKIYE 34714 e-posta: editor@rumelide.com tel: +90 $5057958124,+902167730616$
Address

RumeliDE Journal of Language and Literature Studies Osmanağa Mahallesi, Mürver Çiçeği Sokak, No:14/8

Kadıköy - ISTANBUL / TURKEY 34714

e-mail: editor@rumelide.com,

phone: +90 505 7958124, +90 2167730616 
text could'nt be provided in the target text in the translations of riddles and tongue twisters. For this problems some suggestions have been made through the transcreation. In this context some examples have been presented. The study aims to contribute to translations of Karagöz, ensuring their sustainability through written texts and staging and intercultural dialogue.

Keywords: Translation, Shadow theatre Karagöz, Katharina Reiss' translation criticism approach, transcreation

\section{Giriş}

Geleneksel Türk Tiyatrosunun önemli bir parçası olan Karagöz gölge oyunu UNESCO somut olmayan kültürel miras listesinde yer almaktadır. Bu geleneksel güldürü sanatı günümüzde televizyon, akıllı telefonlar gibi teknoloji ürünlerinin ortaya çıkmasıyla birlikte unutulmaya başlanmıştır. Uluslararası Kukla ve Gölge Oyunu Birliği (UNIMA), Kültür Bakanlı̆̆ı, Akbank Karagöz ve Kukla Tiyatrosu, belediyeler ve hayâli eğitimi almış sayılı ustaların çabalarıyla yaşatılmaya çalışılmaktadır. Bu mirası canlı tutmak, gelecek nesillere aktarmak ve kültürümüzü başka toplumlara aktarmanın yollarından biri yeni Karagöz oyunlarının üretilmesi ve çevirilerinin yapılıp sahnelenmesi yoluyla dünya dolaşımının sağlanmasıdır.

Türk dünyasında karagöz iki anlamı çağrıştırmaktadır. Biri 'Karagöz' adındaki karakter diğeri ise gölge oyunlarının geneline verilen isim (Sakaoğlu, 2011: 18). Bazı Türk ve Arap sûfilerin eserlerinde hayalü'lsitare (perde hayali), zıllu'l-hayal (hayal gölgesi) olarak geçen bu oyun hayal sahnesinin kâinata benzetilerek varlıklar ve mutlak varlık arasındaki ilişkiyi temsil etmiştir (a.g.e.: 31). Karagöz, deve ve manda derisinden yapılan insan, eşya, hayvan tasvirlerinin beyaz perde üzerinde arkadan verilen bir ișık yardımıyla yansımalar sağlanarak canlandırılmasını temel alan bir gölge oyunudur. Karagöz oyunlarını oynatan, seslendiren kişiye ise 'hayali' denir (Mutlu, 1995: 55). Öncelikli özelliği eğlendirmek olan Karagöz oyunlarında musiki, resim, şiir, mizah, edebiyat, dans tasavvuf, hiciv gibi unsurlar da yer almaktadır. Karagöz kahvehanelerin popüler olduğu 16. yüzyıl sonlarında Türkiye'de popüler olmuştur. Daha sonrasında daha çok ramazan ayı boyunca oynatılan bir oyun haline gelmiştir. Böylece Karagöz festival ve dinsel özelliklerin bileşimi olmuştur (Aykaç, 2016:614).

\section{Karagöz gölge oyununun tarihi gelişimi ve yapısal özellikleri}

Karagöz gölge oyunu ile ilgili birçok araştırmacı tarafından incelemeler yapılmış eserler ortaya konmuştur. Oyunun nerede doğup nasıl yayıldığı ile ilgili Asya'da doğup Batı'ya yayılmış olduğu ve Batı'da doğmuş olup Asya'ya yayılmış olduğu şeklinde iki farklı yaklaşım olmuştur. Andreas Tietze (1977: 16-17)'nin vermiş olduğu bilgiye göre Türk Karagöz oyunları 16. yüzyılla anılmakla beraber, 13. yüzyıldaki Çin, Endonezya ve Mısır gölge oyunlarından türemiştir. Bu oyunlar Cava gölge oyunu ile benzerlikler göstermektedir. 1517 yılında Mısır'ı fetheden Yavuz Sultan Selim Memluk Sultanı Tumanbay’ın Roda Adasında asılıșını hayal perdesinde canlandıran bir hayali sanatçısını oğlu Kanuni Sultan Süleyman'ın da görmesi için İstanbul'a getirir (Mutlu, 1995:53). Anadolu'ya oyunun girişi bu şekilde olur. Oyuna zamanla Türk yaratıcılığı katılmış daha renkli ve hareketli özgün bir hale getirilmiştir. Daha sonrasında da Osmanlı imparatorluğu ve çevresinde yayılmıştır (And, 2004: 40). 1582 şenliğini anlatan Sûrnâme-i Hümâyun'da ayrıntlı bir biçimde geçmektedir. Evliya Çelebi'nin kitabında ise oyunun konusu, özellikleri, perde gazelleri ve dönemin oyuncuları hakkında bilgiler yer almaktadır (a.g.e.: 40-42). Çelebi'ye göre Karagöz'ün esas adı Bâli Çelebi'dir ve Padişah Sultan Orhan'ın Bursa'da cami yaptırmaya karar verdiği dönemde bu caminin inşaatında görev alır ve orada ustabaşı Hacı İvaz yani Hacivat'la tanışır. Samiyetleri sohbete dönüşen bu iki arkadaşın eğlenceli diyalogları işçilerin işlerini bırakmalarına sebep olur ve cami inşaatı yavaşlar. Durumu öğrenen

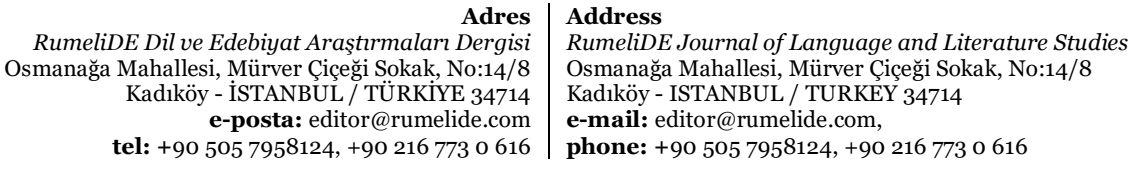


padişah ikisinin de başlarını vurdurarak cezalandırır. Fakat sonra bu duruma çok üzülür. Küşteri adında bir adam padişahın acısını hafifletmek için onlarının gölge kuklalarını yapar ve oynatır. (Mutlu, 1995: 53-54). Bundan dolayı Karagöz Perdesinin diğer bir adı da 'Küşteri Perdesi' dir (Sakaoğlu, 2011: 49). Selim Nüzhet Gerçek (1942: 45)'in George Jacob (1925: 8)'den aktarmış olduğu bilgiye göre ise Çin gölgeleri adı verilen hayal oyunu ilk defa M.Ö. 121 yılında ortaya çıkmıştır. Çok sevdiği eşini kaybeden Çin imparatoru Wu'yu teselli etmek için Sav-Wöng adlı bir sanatkâr bir perde arkasında ölen eşini hatırlatması için gölge bir karakteri oynatmıştır. Karagöz ve Hacivat'ın yaşayıp yaşamadıkları kesin belgelerle ortaya konamamıştır. Karagöz okula gitmemiş okuma ve yazması olmayan ve bu sebeple mesleği olmayan bir kişidir. Bilmediği konularda bile bilmiyorum demez. Açıkgöz ve kurnazdır hiç altta kalmaz fakat kibar konuşmasını da beceremez, duyduğu sözleri yanlış anlayıp uydurma ve saçma cevaplar verir (Oral, 2019: 6). Hacivat ise okumuş çevresinden saygı gören bir kimsedir. Bu sebeple halk tarafından gözü kara, cesur halk temsilcisine Karagöz, okuryazar olan Hacı Evhat 'a da Hacivat denmiştir (Hınçer, 1959). Oyunlarda yer alan diğer tipler ise Çelebi, Tiryaki, Beberuhi, Kambur, Matiz, Cambaz, Zenneler, Külhanbeyi, Kayserili, Kastamonulu, Karadenizli, Rumelili, Bolulu ve diğerleri gibi birçok oyuncudan oluşur (Sakaoğlu, 2011: 183-229). Karagöz oyunu giriş (mukaddime, prolog), muhavere, (söyleşi, diyalog), Oyun (Fasıl) ve Bitiş (Final, Epilog) olmak üzere dört bölümden oluşur. Kamıştan yapılan bir düdüğün (narke) çalmasıyla göstermelik (dekor: ev, bitki vs.) perdeden çekilir. Sonra perdenin sol tarafından semai okuyarak Hacivat gelir (Mutlu, 1995: 55). Semai bittikten sonra "Hây Hâk!" sözlerinden sonra perde gazeli okur. Perde gazeli özel bir şiirdir. Oyunun başlangıcı olarak kabul edilen bu bölüm Hayâl perdesinin tasavvufî yönünü vurgular. Gazel sonunda Hacivat "Yar bana bir eğlence!" der ve Hacivatı perdeye davet eder.

Ünver Oral (2019:9)'ın vermiş olduğu bilgilere göre 'muhavere' Karagöz ve orta oyununda kullanılan bir terimdir ve bir veya birkaç kişinin konuşmasına denmektedir. Asıl oyundan bağımsız olan bu konuşmalar her konuda olabilir. Hatta bu bölümün başına giriş sonuna bitiş eklenerek ve şiir, müzikle zenginleștirilerek tek başına bir gösteri olarak da sunulabilir. Muhaverenin bitişinden sonra asıl oyun başlar ki bu bölüme 'Fasıl' denir. Bu bölümde çeşitli tipler perdeye gelir ve oyun hareketlenir. Bitiş bölümü genellikle Hacivat'ın "Ylktın perdeyi eyledin viran / Varayım sahibine haber vereyim heman" sözleriyle biten bölümdür. Karagöz oyununun oynatımındaki en önemli unsurlardan biri de doğaçlama tekniğidir. Buna 'Tulûat' denilir. Duruma göre hâyali doğaçlama (tulûat) tekniğine başvurabilir. Bu teknik, özel yetenek, bilgi ve kültür gerektirir (Oral, 2019: 23). Karagöz gölge oyunu metinlerinde bilmece, tekerleme, ikileme, şive, türkü gibi kültüre özgü ögelere sıkça yer verildiği görülür.

\section{Kuramsal çerçeve}

Çeviri, bir eserin dünya dolaşımı ve tanıtımının en etkin yollarından biridir. Geleneksel tiyatromuzun önemli bir parçası olan 'Karagöz Gölge Oyunu' kültürlerarası iletilişim açısından da önemli bir misyona sahiptir. Bu görevi en güzel ve en etkin şekilde yerine getirebilmesi için sürekliliğinin sağlanması ve çevirilerinin en güzel şekilde yapılması gerekmektedir. Çalışmanın bu bölümünde öncelikle diğer çeviri türlerine göre daha farklı özellikler gerektiren tiyatro çevirisi ve çevirilerin farklı yönleriyle kapsamlı şekilde ele alınmasını sağlayan çeviri eleştirisi konuları ele alınacaktır. Daha sonrasında bu kapsamda Katharina Reiss'ın çeviri eleştirisi yaklaşımı ve bu yaklaşım doğrultusunda incelenmiş olan Selected Stories of Hacivat and Karagöz adlı eserden çeviri örnekleri sunulacaktır. İncelenmiş olan örnekler sonucunda tespit edilen çeviri sorunları yaratıcı metin uyarlaması (transcreation) kavramı çerçevesinde değerlendirilecek, yapılmış Türkçe ve İngilizce örnek çalışmalar doğrultusunda öneriler sunulacaktır.

\subsection{Tiyatro çevirisi}

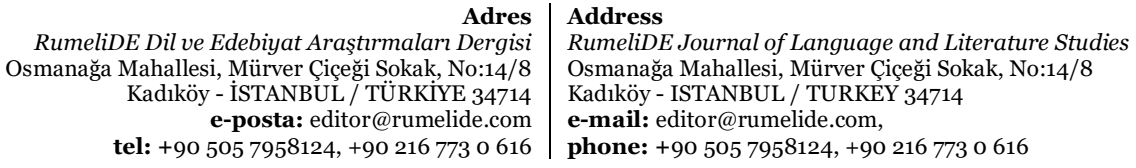

RumeliDE Dil ve Edebiyat Araştırmaları Dergisi tel: +90 505 7958124, +90 2167730616 
Tiyatro çevirisi kaynak metnin ne dediğini anlamak onu hedef dile aktarmak ve bunu yaparken aynı zamanda yorumlayabilmek demektir. Bazen bu durum yeniden yazmayı, uyarlamayı hatta metnin yeniden yaratılmasını gerektirebilir. Tiyatro çevirisi karakterlerin konuşması, görüntüsü, söylemleri gibi artı unsurlar içerdiği için çoklu yaklaşım gerektirmektedir. Dolayısıyla tiyatro çevirmeninden beklenen anlaşllabilir, söylenebilir ve sahnelenebilir bir ürün ortaya çıkarmasıdır. Bu sebeple çevirmen çeviriye bazen oyuncu, bazen yönetmen bazen de izleyici gözüyle bakabilmelidir. Böylece kaynak metindeki etkiyi hedef metinde yaratmayı başarabilecektir. Ülkemizde tiyatro çevirisine yönelik kuramsal çalışmalar sınırlı sayıdadır. Beki Haleva (2011: 33) yapmış doktora tezi çalışmasında bu konuya değinmiş, dünyadan ve Türkiye'den araștırmacıların konuya yönelik çalıșmalarıyla ilgili bilgiler sunmuștur. Bu kapsamda Ortrun Zuber-Skerritt'den (1984) bahsetmiş Skerritt'in tiyatro çevirisini yazınsal metinden ayrıștıran iki özelliğe; oynanabilir ve söylenebilir olmasına vurgu yaptı̆̆ını ifade etmiştir. Ona göre çevirmen metnin tiyatral kısmı ile de ilgilenmeli ve çevirme eyleminden önce eseri izlemelidir. Haleva (2011:33-36) çalışmasında tiyatro göstergebilimi üzerinde çalışmış olan Susan Bassnett ve Patris Pavis isimlerine de yer vermiştir. Roger Pulvers, Anne Ubersfield, Aoltonen de bu alanda çalışmaları olan isimler arasındadır. Yapılan çalışmaların ortak noktası tiyatro çevirisinin özel bir alan olduğudur. Bu çalışmalarda en sık geçen kavramlar ise sahnelenebilirlik, kültürel kabul, karakterlerin kendilerine özgü söylemleri olmuștur. Türkiye'deki yaklaşımlar üzerinde de duran Haleva Özdemir Nutku'nun alanla ilgili çalışmalarına değinmiş onun sözcüğün sözlük anlamı değil oyundaki işlevine vurgu yaptığını dolayısıyla dilin farklılığına vurgu yaptığını dile getirmiştir. Yani tiyatro çevirisinde yazınsal dil değil güncel konuşma dili kullanılmalıdır (Nutku, 1978:81'den aktaran Haleva, 2011: 44). Ülkemizde yabancı dillerden Türkçeye ve Türkçeden yabancı dillere çevrilmiş ve uyarlanmış eserler mevcuttur. Ayrıca Türk oyunlarının yabancı dillere çevrilmesine ön ayak olan ve UNESCO'nun bir kolu olan International Theatre Institute (ITI) Uluslararası Tiyatro Enstitüsü mevcuttur. Melahat Özgü, Rudolf Fahner, Nüvit Özdoğru, Carolyn Graham, Tahsin Saraç, René Giraud, Sezen Duru, Nermin Menemencioğlu Türkçeden yabancı dillere çevrilen tiyatro eserlerinde adı geçen çevirmenlerdir (Zeytinkaya, 2018: 290).

\section{2. Çeviri eleştirisi}

Çeviri eleştirisi çeviri metnin kapsamlı bir şekilde hem dilsel hem de dil dışı öğeler doğrultusunda incelenmesini gerektirir. Çeviri eleştirisi ilk zamanlar kaynak metin odaklı gerçekleşmiştir. Kaynak metne eşdeğer çeviri kabul görmüştür ve metne eşdeğer olmayan çeviri hatalı kabul edilmiştir. Eşdeğerlik kavramı dilsel bağlamda ele alınmıș dil dışı öğeler göz ardı edilmiștir. Bu yaklaşımlar çeviri eleștirisinin bilimsel bir yapıya kavuşmasını sağlayamamıștır. Özellikle kaynak metne bağlılığın esas alındığı kutsal metin çevirileri dönemi bu sürecin uzamasına yol açmıştır. Nida (1975:123-135) kutsal metinlerin dilsel eşdeğerliliğinin yerine çevirinin erek kültürde kaynak kültürdekine benzer bir etki yaratması gereği üzerinde durmuştur ve bu etkinin sadece dilsel göstergeler ölçüt alınarak yaratılamayacağının alıını çizmiştir. Çeviri eleştirisine olan yönelim dilbilimsel yaklaşımlarla artmış ve yeni arayışlar başlamıştır. Werner Koller, Wolfram Wills, Juliane House gibi çeviri kuramcıları erek metnin özelliklerini temel alan bir yaklaşım içinde olmuşlardır. Koller (1997:228-265) kaynak metni düz anlamsal, metinsel, paragmatik ve biçimsel açıdan incelerken, House (2002), metnin erek metindeki işlevine göre değerlendirilmesi gerektiğini öne sürmüștür. Christiane Nord (1995) karşılaştırmanın gerekliliğini ve çeviri eleştirisine ilişkin ölçütler olması gerektiğini savunmuştur. 1970 ve 80'li yıllarda Katherine Reiss, kültürlerarası iletişim açısından metin türü kavramını gündeme getirmiştir. Reiss'ın çalışmaları Hans Vermeer'in skopos kuramına öncülük etmiştir. 1984 yılında Hans J. Vermeer ile yapmış oldukları Ground Work for General Theory of Translation başlıklı çalışmalar ile çeviriye işlevsel bir yaklaşım getirmişlerdir (Munday, 2001:79).

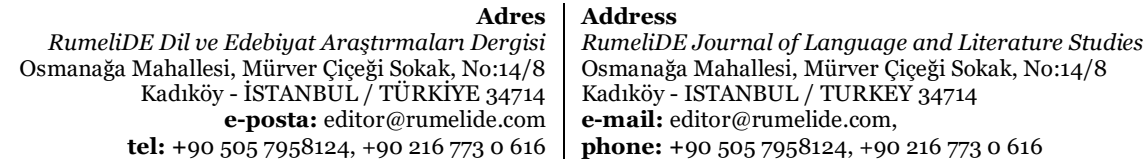


Türkiye'de çeviri eleştirisi Nurullah Ataç, Bedrettin Tuncel, Sabahattin Eyüboğlu ve sonrasında Akşit Göktürk, Tahsin Yücel, Ahmet Cemal gibi isimlerin çeviri eleştirisi alanına yönelimleriyle başlamış, 1940'larda başlayan çeviri dergileri etkinlikleriyle devam etmiştir. Bunlara örnek olarak Emine Bogenç Demirel ve Hülya Yılmaz'ın Tercüme, Yazko ve Metis çeviri dergilerinde Çeviri Eleştirisinin Türkiye Serüveni başlıklı bildirilerinde Nusret Hızır gibi eleştirmenlerin arayışlarının kuramsallığa geçişteki önemine vurgu yapmışlardır. Yazko çeviri dergisi çeviribilime ayırmış olduğu özel bölümü ile çeviri eleştirisine yapıcı bir statü kazandırmıştır. Onu Metis dergisi takip etmiştir. Bu alanda akademik çalışmalar da yapılmıştır (Haleva,2001:7-8). Bunlardan birisi de Hasan Anamur'un çeviri işleminde karşılaşılabilecek problemleri beş ayrı düzeyde nesnel saptama ve eleștirme aracı olarak sunduğu "Beş Düzeyli Nesnel Çeviri Eleştirisi Yöntemi" dir (Anamur, 1998: 1-13). Bu eleștiri yöntemi çevirmenin yazarın eserini çok iyi anlayıp ekinsel ve biçimsel ve etkisel eşdeğerlikle yeniden üretmesi gerektiğini vurgulamaktadır. Bu bağlamda metnin düzanlamsal, yananlamsal, biçimsel, uygulama ve etkileme düzeyinde değerlendirilmesini önermiştir.

\subsection{Katharina Reiss'ın çeviri eleştirisi yaklaşımı ve metin türü kavramı}

Katharina Reiss, Karl Bühler'in bilgilendirici, anlatımcı ve işlemci olmak üzere üç dilsel işlevi ve oluşturdukları farklı metin türleri düşüncesinden yola çıkarak bir model geliştirmiş ve dört metin türü belirlemiştir: bilgilendirici metin, yazınsal metin, işlemsel metin, görsel ve işitsel metin. Reiss (2014: 66) kültürlerarası bildirişimin sözcük ve tümce düzeyinden çok metin düzeyinde ele alınmasını savunmuştur. Genel çeviri metodunu metnin türünün belirlediğini ifade etmiștir.. Reiss (a.g.e.: 31)'a göre bilgilendirici metinler içerik odaklı metinlerdir. Bu metinlerde biçim değil içerik önemli olduğundan bu metinler içeriğinden bir şey kaybetmemelidir. Haber, bildiri, rapor, tez, kullanma kılavuzu gibi ürünler bu grupta yer alır.). Yazınsal metinler ise biçim odaklıdır. Bu sebeple bu metinler, estetik ögeleri göz önünde bulundurularak ve bu yönde eşdeğerliği sağlanarak çevrilmelidir. Şiir, roman, hikâye, deneme, fikra türleri bu gurupta yer alır. İşlemsel metinler ikna odaklı metinlerdir ve kaynak metindeki etki erek metinde de sağlanacak şekilde çevrilmelidir. Bu gurupta reklam metinleri, çeşitli broşürler, ilânlar, tanıtım afişleri yer alabilir (a.g.e.: 34-39). Reiss 'ın görsel-işitsel olarak adlandırdığı grupta yer alan türler ise daha çok okunmak için değil dinlenmek ya da izlenmek içindir. Yazılan bu metinler ikna odaklı metinlerde olduğu gibi kaynak dilde oluşturduğu etkiyi hedef dilde de oluşturabilmelidir. Çeviriler bunu sağlayacak yönde yapılmalıdır. Tiyatro ürünleri, oyunlar, gösteriler, radyo programları bu guruba dahildir (a.g.e.: 43-44). Bazen bir metin bu dört metin türünün özelliklerini aynı anda taşıyabilir.

Reiss'ın yaklaşımına göre 'Nesnel Çeviri Yaklaşımı' olumlu veya olumsuz mutlaka açık ve doğrulanmış örneklerle tanımlanmış olmalıdır (a.g.e.: 7). Bu anlamda öncelikle metnin türü belirlenmeli ve türüne göre metin hem dilsel ögeler hem de dile ilave ögeler açısından değerlendirilmelidir (a.g.e.: 94). Reiss çeviri eleştirisini üç başlık altında toplamaktadır. Birincisi metin türünün belirlenmesidir (yazınsal bağlam).Bu işlemden sonra metnin dil içi öğelere göre değerlendirilmesi (dilsel bağlam), daha sonrasında da dile ilave öğelere (edimbilimsel bağlam) göre değerlendirilmesi gerekmektedir. Dil içi öğeler erek metindeki sözcük seçimleri, dil bilgisel ve biçimsel öğeler olurken dile ilave öğeleri erek metnin durum, zaman, yer özellikleri oluşturur.

\subsubsection{Dil içi öğeler}

Reiss'ın dil içi ögeler olarak adlandırdığı ögeler arasında anlamsal ögeler, sözcüksel ögeler, dilbilgisel ögeler, uslûpla ilgili faktörler yer almaktadır.

\subsubsection{Anlamsal ögeler (Semantic elements)}

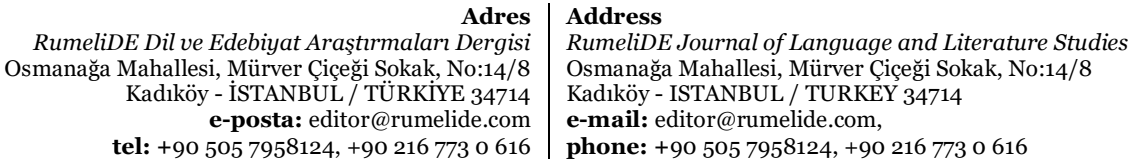

RumeliDE Dil ve Edebiyat Araşturmaları Dergis Kadıöy - ISTANBUL /TÜRKIYE tel: +90 $5057958124,+902167730616$ 
Çeviride anlamsal açıdan değerlendirmede "Çevirmen söylenen ifade ile ne demek istemiştir?" sorusu karşılaştırmalı olarak değerlendirilmelidir. Bu noktada çevirmen yanlış yorumlama, keyfi eklemeler ve eksiltmeler, anlamsal tezatlıklar, çok anlamlı ifadeler, eş sesli kelimeler konularında dikkatli olmalıdır. Metni sadece sözcük, cümle (micro context) ya da paragraf olarak görmemeli, bir bütün (macro context) olarak değerlendirmelidir (Reiss, 2014:53).

\subsubsection{Sözcüksel öğeler (Lexical components)}

"Sözcüksel öğelerin değerlendirilmesinde kaynak dilde var olan kelimelerin erek dilde yeterliliği sağlanabilmiş midir?" ve "Kelimeler doğru şekilde kullanılmış mıdır?" sorularına yanıt aranmalıdır. Diller arasındaki farklılıklardan dolayı sözcüklerde yapısal ve kavramsal farklılıklar olabilmektedir. Metin kelime oyunları, deyimsel ifadeler, mecaz kelimeler, teknik kelimeler, erek kültürde eşdeğeri olmayan kelimeler, atasözleri, sık karıștırılan kelimeler, eş sesli kelimeler açısından dikkatle değerlendirilmelidir (a.g.e.: 57).

\subsubsection{Dilbilgisel öğeler}

Kök, söz dizimi, dilbilgisi kuralına uyum gibi unsurlar göz ardı edildiğinde cümlenin anlamı bozulmakta ve değisşebilmektedir. Bu sebeple çevirmenin kaynak ve erek dilin yapısını ve dilbilgisi kurallarını çok iyi bilmesi gerekmektedir. (a.g.e.:60)

\subsubsection{Uslûpla ilgili faktörler}

Konuşma dili, resmi kullanımlar, günlük ifadeler, yöresel kültürel, edebî ifadeler toplumdan topluma değişiklik gösterebilmektedir. Bu sebeple çevirmenin her iki dile de hâkim olması gerekmektedir. Aynı biçimsel ve anlamsal etkiyi yaratmak için yaratıcı olması, uygun eşdeğerlik için uyarlama yapması gerekebilir (a.g.e.: 63)

Tüm bu öğeler metnin değerlendirmesi yapılırken bir bütün olarak değerlendirilmelidir. Çünkü her biri birbiriyle ilişkili ve metin türüyle bağlantılıdır.

\section{3•3.2. Dil dışı öğeler (Extra linguistic elements)}

Reiss (a.g.e.: 66-90), çeviri eleştirisinde sadece dil içi öğelerin yeterli olmadığının dile ilave öğelerin de metnin anlamını etkilediğinin altını çizmektedir. Reiss tarafından bu öğeler anlık durum, konu ve alan bilgisi, zaman faktörü, yer faktörü, konuşmacı-yazar faktörü, etkili ifadeler olarak tanımlanmıștır.

\subsubsection{Immediate situation (Anlık durum)}

Çeviri sürecinde bir kelimenin veya ifadenin hedef dilde birden fazla karşıllı̆̆ olabilmektedir. Bu karşılıkların seçimini bazen anlık durumlar belirler. Ünlem kullanımı, imalar, yazın eserleri, tarihi olaylar, konuşma diline özgü kısaltılmış ifadeler, italik yazımlar çeviriyi güçleştirebilir. Çevirmenin bunların araştırmasını iyi yapması ve kendisini konuşmacının ve dinleyicinin yerine koyması gerekir. Çeviri eleştirmeni de aynı şekilde karşılıkları bulurken anlık durumları, anlamsal karşılıkları göz önünde bulundurmalıdır (a.g.e.: 68-69).

\subsection{2. Alan ve konu bilgisi}

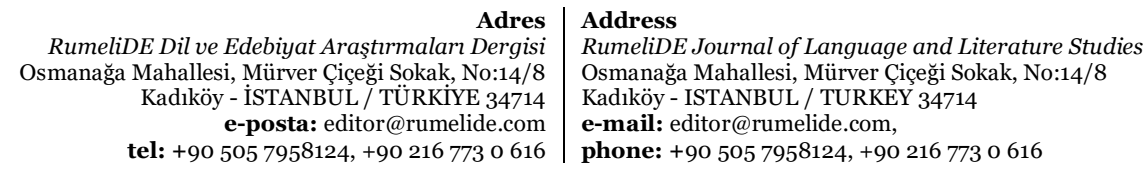


Dil dışı öğeler kapsamında değerlendirilen bir başka unsur da konu ve alan unsurudur. Çevirisi yapılacak ya da çeviri eşleştirişi yapılacak metnin konusu ile ilgili yeterli bilgiye sahip olmak gereklidir. Çevirmen alana hâkim olmalı ve çevirisini alana ait bilgileri göz önünde bulundurarak yapmalıdır. Bu noktada bazen kelimelerin etimolojik bilgisine, dönemsel kullanımlarına ihtiyaç duyulabilir. Bu sebeple alanla ilgili terminolojiyi de iyi bilmek gerekmektedir. (a.g.e.:70-71).

\subsubsection{Zaman faktörü}

Eğer metin eski veya belirli bir dönemde oluşturulmuş ise kelimelerin ve olayların döneme ait unsurlar içermesi muhtemeldir. Bu durum çeviri eleştirisini de etkileyecektir. Özellikle eski dildeki metinlerin çevirisinde kelime seçimi, eskimiş morfolojik ve söz dizimsel formlar çeviriyi ve çeviri eleştirisini güçleştirebilir. Günümüz okuyucu kitlesi için eski eserlerin dili kolay anlaşılır olmayabilir bu sebeple klasik eserlerin zaman zaman güncellemeleri yapılmakta ve yeniden basılmaktadır (a.g.e.: 71-72).

\subsubsection{Yer faktörü}

Zaman faktörü de yer faktörü gibi çeviri ve çeviri eleştirisini çok yönlü bir şekilde etkilemektedir. Çeviride kaynak dilin içinde yer aldığı kültürü ve özelliklerinin erek metne en iyi şekilde yansıtılabilmesi için kültüre özgü dil kullanımının, gelenek ve göreneklerin iyi bilinmesi gerekmektedir. Çünkü nesnel bir çeviri eleştirisi için sadece dili bilmek yeterli değildir (a.g.e.: 74-76).

\subsubsection{Okuyucu ve izleyici faktörü}

Kaynak metnin kim için yazıldığı ve hazırlandığı metnin çevirisi ve eleştirisini de doğrudan etkileyecektir. Sözgelimi kaynak metin çocuklar için yazılmış bir metin ise kelime seçimleri ona göre yapılacak, çeviri eleştirisi bu yönde olacaktır. Kaynak metin bir tiyatro eseri ise çeviri tercihi konuşma metni doğrultusunda olacaktır. Bu noktada yer faktöründe olduğu gibi okuyucu ve izleyici faktöründe de sosyal ve kültürel bağlamın bilinmesi büyük önem arz etmektedir. Deyimsel ifadeler, imâlar ve mecazların okuyucu ve dinleyici için anlaşılabilir olması göz önünde bulundurulması gereken unsurlardır (a.g.e.: 78-79).

\subsubsection{Konuşmacı ve yazar faktörü}

Konuşmacı ve yazar faktörü yazarın dilini etkileyen, hikayedeki karakterlerin konuşmalarına yansıyan unsurlardır. Bu unsurlarda metnin türü yine oldukça etkilidir. Özellikle şiir, roman gibi türlerde yazarın yaşantısından, almış olduğu eğitimden, yaşamış olduğu zamandan izler görülebilir. Çevirmenin veya çeviri eleștirmeninin bununla ilgili bilgisinin olması gereklidir. Döneme ait özellikler, kültürel bağlam karakterlerin konuşmalarına yansıyabilir. Her konuşma karakterin rollerine uygun tonlama ve konuşma tarzı içerebilir (a.g.e.: 82).

\subsubsection{Etki faktörü}

Duygusal belirleyiciler sözcüksel ve biçimsel öğeleri etkilemekte dilbilgisel düzeyleri, cümle yapılarını dolayısıyla tüm metni etkileyen unsurlar arasındadır. Eleştirmen bu tür imâların, vurguların yansıtılıp yansıtalamadığını incelemeli, kaynak metindeki mizahın, yerginin, taşlamanın yarattığı etkinin erek dilde yaratılıp yaratılamadı̆̆ını tespit etmelidir (a.g.e: 83).

Öncesinde de belirtildiği gibi çeviri eleştirisi için birçok görüş ortaya atılmıştır. Fakat Reiss kültürden kültüre farklılık gösteren durumları da içeren, birçok türü kapsayan kapsamlı bir çeviri eleştirisi modeli

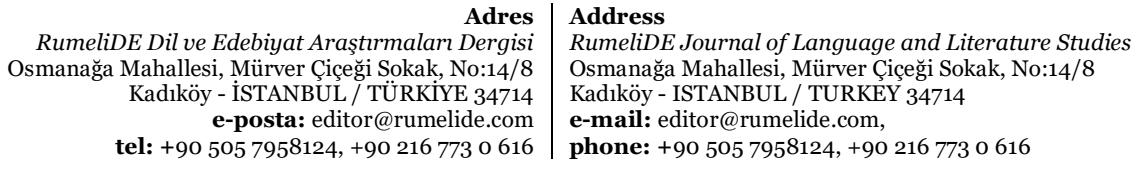


ortaya koymuştur. Çeviri eleştirisinin sadece dilsel öğelerin incelenmesiyle yapılamayacağının, okuyucu, dinleyici, yer, zaman faktörü gibi unsurların da incelemede göz önünde bulundurulması gerektiğinin önemini vurgulamıştır.

\section{Uygulama örnekleri}

Çalışmanın bu bölümünde Profil yayıncılığa ait Selected Stories of Hacivat and Karagöz (2007) eseri aynı yayıncılığa ait kaynak metin Seçme Hikâyeler Hacivat ve Karagöz (2007) eseri ile karşılaştırmalı olarak Reiss'ın çeviri eleştirisi doğrultusunda incelenecek ve değerlendirilecektir. Reiss'ın çeviri eleştirisi yaklaşımına göre nesnel bir çeviri eleştirisi örneklerle doğrulanmalı ve yapılan eleştiri yapıcı olmalı eksikliklerin giderilmesi için öneriler sunulmalıdır. Bu kapsamda çeviri eleştirisi adı geçen eserden seçilmiş olan çeviri örnekleri üzerinden gerçekleştirilecek, inceleme ve değerlendirme verileri sonuçlarına göre yaratıcı metin uyarlaması (transcreation) kavramı üzerinden yapılan çalışmalar doğrultusunda öneriler sunulacaktır.

Reiss (2014)'a göre çevirmen bir metni çevirmeden önce metin türünün farkında olmalıdır. Çünkü her metin kendi içinde değerlendirilmelidir. Örneğin içerik ya da biçim odaklı türler için kelimelere sadakat, gramer ve biçim öncelik taşırken, bir oyun için hedef dilde yaratacă̆ı etki ön plandadır. Karagöz Gölge Oyunu bir tiyatro türüdür. İncelenecek eserin başlığı Selected Stories of Hacivat and Karagöz'dür. Bu başlıkla eser hikâye türü olarak tanıtılmaktadır. Eserin içeriğine bakıldığında ise tiyatroya özgü diyalogların yer aldığı görülmektedir. Buna karşın çeviri diyaloglarda yer alan cümlelerin çoğunun günlük konuşma dilini yansıtmadığı, bir tiyato metni için söylenmesi zor, uzun ve daha çok yazı diline özgü dilbilgisel cümlelerden oluştuğu görülmektedir.

\section{Örnek 1}

\section{Kaynak metin}

"Efendim dilimden anlayacak bir arkadaşım olsa şöyle aşağı gelse ben söylesem o dinlese o söylese ben dinlesem." (s.6).

\section{Erek metin}

"I wish I had a friend who could understand me and to whom I could tell my grief and to me he could tell his grief" (pg. 6).

Erek metne aktarılan cümlede konuşma diline özgü olmayan gereksiz dilbilgisel eklerin kullanıldığl,, Hacivat'ın Karagözü yanına çağırmasının göstergesi olan 'aşağı gelse' ifadesinin silindiği gözlemlenmektedir.

\section{Örnek 2}

\section{Kaynak metin}

"Ben sana demedim mi evde çocuk uyuyor diye" (s.6).

\section{Erek metin}

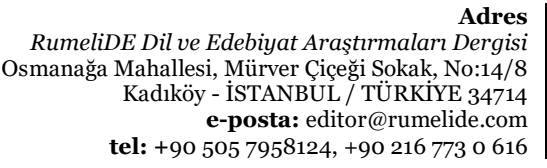

dres

(⿻)

RumeliDE Journal of Language and Literature Studies

Osmanağa Mahallesi, Mürver Çiçeği Sokak, No:14/8

Kadıköy - ISTANBUL / TURKEY 34714

e-mail: editor@rumelide.com,

phone: +90 5057958124 , +90 2167730616 
"Havent I just told you that there is a child sleeping in the house? (pg. 6). Bu ifadenin yerine konuşma cümlesi olarak "Just told you the child is sleeping in the house" gibi daha kısa ve söylenebilirliği daha kolay bir cümle tercih edilebilirdi.

\section{Örnek 3}

\section{Kaynak metin}

"Hiç düşünmez ki bu evde çocuk mu uyuyor, Karagöz gazete mi okuyor, yemek mi yiyor yoksa misafir mi var. Aaah, Ah!" (s.6).

\section{Erek metin}

“He doesn't take into considiration whether there is a child sleeping in the house or not. He doesn't take into consideration whether Karagoz is reading a newpaper, having his lunch or whether he has a guest in the house. Ah ah!" (pg. 6-7). Verilen cümlenin kaynak metindekinden oldukça uzun olduğu görülmektedir. Burada "take into considiration" kelimesinin yerine gündelik konuşma dilinde sıkça kullanılan 'not care' gibi bir ifade seçimi ve aynı ifadelerin tekrarı yerine "and" bağlacı ile diğer eylemlerin tek bir özneye bağlanması daha uygundur.

\section{Örnek 4}

\section{Kaynak metin}

"Bunu bilmeyecek ne var?" (s.7)

\section{Erek metin}

"Is that possible that anybody can not know this?" (pg. 7).

'Bunu bilenmeyecek ne var?' deyimsel bir ifadedir ve bir şeyin çok kolay olduğunu anlatmak için kullanılır. İngilizce de konuşma dilinde deyimsel ifade olarak bir şeyin çok kolay olduğunu ifade etmek için "it is a piece of cake" cümlesi sıkça kullanılan deyimlerden biridir. Bu veya benzeri bir ifade erek kültürdeki anlamı karşılamak için daha uygundur.

Benzer şekilde "Do you want me ask another one?" ifadesi kaynak metinde yer alan "Başka sorayım mı?" (2007: 8) cümlesinin karşllığı olarak kullanılmıştır. Bu çeviri cümle uzun ve resmi bir kullanımdır. Karagöz ve Hacivat'ın yakın arkadaş oluşu göz önünde bulundurulduğunda "Shall I ask another?" daha uygun bir kullanımdır. .

\section{Örnek 5}

\section{Kaynak metin}

"Kazan bu kazan bak nasıl karnın doyacak" (s.21)

\section{Erek metin}

"It's a couldron, believe me. Eat it and you' ll see that you will be full when you finish that bowl" (pg. 21)

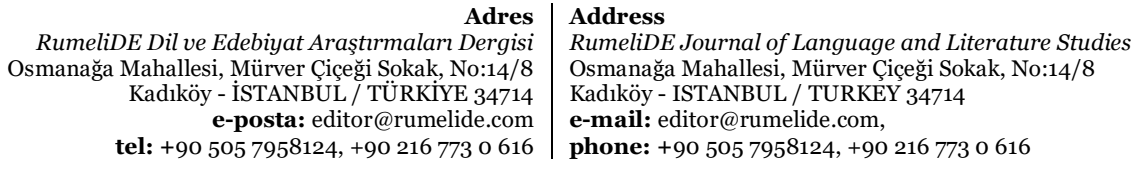


Erek metne aktarılan cümle kaynak metinle karşılaştırıldığında oldukça uzundur. Bunun bir tiyatro eseri olduğu göz önünde bulundurulduğunda, karşllıklı bir diyalog için uygun görünmemektedir. Reiss metnin çevirisine başlamadan önce metnin türünün belirlenmesi gerektiğini ve çevirinin metnin türü göz önünde bulundurularak yapılması gerektiğini vurgulamaktadır. Tiyatro türü metinler görsel ve işitsel odaklı olduğu için içerik ve biçimden daha öncelikli olarak söylenebilirliği ve sahnelenebilirliği dikkate alınmalıdır. Bir yazın metnine kıyasla yazı dilinden çok konuşma dili kullanılmalıdır.

\subsection{Selected stories of Hacivat and Karagöz eserinin dil içi öğeler açısından incelenmesi}

Dil içi öğelerin incelenmesinde çalışmada daha öncesinde de ifade edildiği gibi anlamsal unsurların belirlenmesi, sözcük kullanımı ve yeterliliğinin incelenmesi, dilbilgisel öğelerin doğru ve yerinde kullanılıp kullanılmadığının tespit edilmesi ve dilin uslûp açısından değerlendirilmesi süreçleri yer almaktadır. Anlamsal unsurlar yönünden ele alındığında çeviri eserde dikkati çeken en önemli unsur bazı kelimelerin kaynak metinde yer alan anlamsal eşdeğerinin erek metinde yeterince sağlanamamasıdır. Çeviri eserde bilmece için 'enigma' kelimesi kullanılmıştır (2007: 7). Türkçe olarak muamma, bilmece, gizem anlamlarına gelmektedir. Fakat çoğunlukla çözümlenmesi gereken durumlar, olaylar için kullanılan enigma kelimesinin yerine daha yaygın biçimde dil oyunu ve bilmece için 'riddle' kelimesi kullanılmaktadır. Eserin sekizinci sayfasında geçen 'blue atlas' ifadesinde yer alan 'atlas' Arapça kökenli bir kelime olup "yüzü parlak, sık dokunmuş bir ipekli kumaş türü, saten”( https://sozluk.gov.tr/, 19.06.2021) anlamlarına gelmektedir. İngilizceye çevrilmiş tekerleme içerisinde kaynak dilde olduğu gibi bırakıldı̆̆ı gözlemlenmektedir. Kelime ile ilgili olarak herhangi bir dipnot veya açıklayıcı bilgi sunulmamıştır. Dolayısıyla erek kültür için anlamı bilinmeyen bir kelime olarak kalmıştır. Çeviri eserin on altıncı sayfasında geçen 'dükkân' kelimesi ile lokanta kastedilmektedir. Bu bağlamdan bağımsız olarak çeviri metinde bu kelimeye karşılık olarak 'store' kelimesinin kullanıldığı gözlemlenmektedir. 'store' Türkçe olarak "mağaza, depo" anlamlarına gelmekte kaynak metinde geçen restoranı ifade eden 'dükkân' kelimesini karşlayamamakta anlam karmaşasına neden olmaktadır. Kelimelerin erek dilde eşdeğerlerinin bulunması kaynak metnin bir bütün olarak değerlendirilmesini (macrocontext) ve yorumlanmasını gerektirebilir. Sözcüksel öğeler düzeyinde çeviri eserde birçok deyimsel ifade, kelime oyunları, mecaz kelimeler, bilmeceler, tekerlemeler, atasözü yer almaktadır. Çeviri eserde bu öğelerin çevirilerinde kelimesi kelimesine çeviri yönteminin tercih edildiği ve bu yöntemin erek dilde amaçlanan işlevi yerine getiremediği, kaynak metindeki anlamı sağlayamadığı gözlemlenmiştir. Aşağıda kaynak metindeki bu kullanımların incelenen İngilizce eserdeki çeviri örnekleri sunulmuştur. Kaynak metinde yer alan deyimsel ifadelerin çevirisinin kelimesi kelimesine yapıldığı gözlemlenmekte ve bu durumun kaynak metindeki mizahın erek metinde anlaşılamamasına yol açtı̆̆ı görülmektedir.

\section{Örnek 6}

\section{Kaynak metin}

“Eee, Hacivat o da işin şakası!” (s. 10)

\section{Erek metin}

"That's the witty part of the enigma" (pg. 10)

Çeviri cümlede, kaynak metindeki cümlede yer alan samimi hava ve mizah etkisinin sağlanamadığı görülmektedir. Bir başka deyim örneğinde ise kelimesi kelimesine yapılan çeviri anlamsız bir ifade ortaya

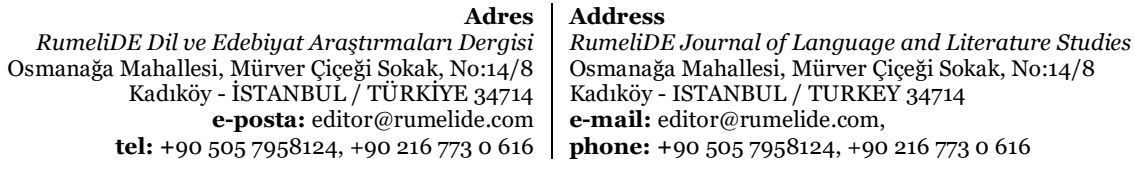


çıkarmış, sözcüklerin ardı sıra sıralanması kaynak metindeki mecazi anlamı sağlamak için yeterli olmamıştır.

\section{Örnek 7}

\section{Kaynak metin}

"Vay Karagözüm sen mürekkep yaladın mı? (s. 12)

\section{Erek metin}

“Ooo, Karagöz have you got the taste of the Ink? (pg. 13)

Eserde yer alan sözcüksel öğe örneklerinden biri de kelime oyunlarıdır. Kelime oyunu bazen kelimelerin yer değişimiyle bazen de ses benzerliği yoluyla yapılmaktadır. Eserin yedinci ve on altıncı sayfalarında geçen Karagöz ve Hacivat' a ait cümlelerde kelime oyunu yer almaktadır.

\section{Örnek 8}

\section{Kaynak metin}

Hacivat: "Öyle olmaz efendim"

Karagöz: "Öğle değilse ikindidir efendim”.

\section{Erek metin}

Hacivat: "It is not like that"

Karagöz: "If its is not like that it is mid afternoon"

\section{Örnek 9}

\section{Kaynak metin}

"Senedim de var sepetimde var."

\section{Erek metin}

"I have both voucher and basket" kaynak metinde yer alan kelimelerle erek metindeki kelimeler arasında ses benzerliği olmadığı için kaynak metindeki kelime oyunu erek metinde sağlanamamıştır. Kaynak metinde yer alan kelimelerin erek metne doğrudan aktarımı kaynak metinde ses benzerliği ve kelime oyunu ile sağlanmış olan mizah etkisini erek metinde sağlayamamıș, anlamsız bir söz dizimi ortaya çıkmıștır.

Sözcüksel bağlamda incelenen diğer öğeler ise tekerleme sözcükler ve bilmecelerdir. Tekerleme ve bilmecelerin en önemli özelliği kafiyeli olmalarıdır. Așağıda yer alan örneklerin çevirilerinde bu uyumun sağlanamadığı dolayısıyla düz cümle olarak çevrildikleri görülmektedir. Bu sebeple kaynak metindeki bilmece ve tekerlemelerde yer alan eğlence ve ses uyumu etkisi erek metinde sağlanamamıştır.

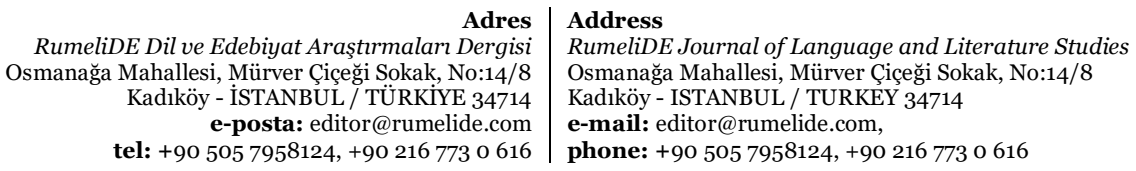




\section{Örnek 10}

\section{Kaynak metin}

“Öldüm, bayıldım, minderler gibi yerlere yayıldım” (s.6)

\section{Erek metin}

"I have died, I have fainted. I overspread the floor like a cushion" (s. 6)

Erek metne aktarılan cümlede kaynak metinde olduğu gibi ilk iki kelimede kafiye sağlanmıştır, fakat üçüncü kelimede aynı etki yaratılamamıștır. Aşağıdaki bilmece örneklerinde de benzer durum söz konusudur.

\section{Örnek 11}

\section{Kaynak metin}

"Sira sira odalar birbirini kovalar"

\section{Erek metin}

"A sequence of rooms following up eachother"

\section{Örnek 12}

\section{Kaynak metin}

“Şekere benzer tadı yok, gökte uçar kanadı yok” (s. 7)

\section{Erek metin}

“It looks like a sugar but it hasn'nt got a taste, it flies in the air but it doesn't have wings" (pg. 7)

Bilmeceleri eğlenceli hale getiren ses uyumunun erek metne aktarımında aynı etkinin sağlanamadığı görülmektedir.

Reiss'ın çeviri eleştirisi yaklaşımına göre dil içi öğeler kapsamında çeviri eleştirisi söz dizimi, dilbilgisi kurallarına uygunluk açısından da değerlendirilmelidir. Çeviri eser bu bağlamda dil bilgisi yönünden de incelenmiş ve dilbilgisi açısından yanlış çeviri örnekleri tespit edilmiştir. Bu örnek şu şeklidedir:

\section{Örnek 13}

\section{Kaynak metin}

"İs de olur, kurum da olur" (s. 20)

\section{Erek metin}

"There is either a job or an institution" (pg. 19)

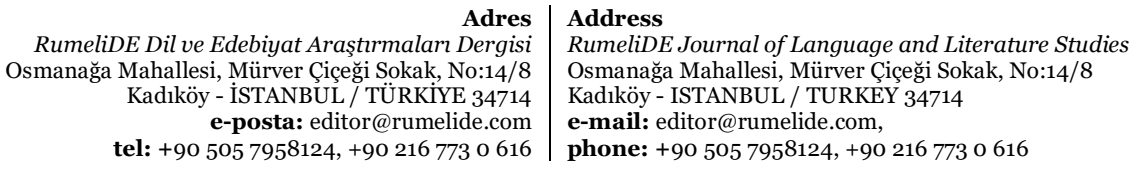


Kaynak metinde yer alan cümlenin erek dile "Ya iş olur ya da kurum olur "şeklinde yanlış dilbilgisi kalıbıyla ve 'is' yerine iş anlamına gelen 'job' kelimesiyle aktarıldığı görülmektedir. Benzer şekilde aşağıdaki örnekte de yanlıs gramer kullanımı mevcuttur.

\section{Örnek 14}

\section{Kaynak metin}

"Ben okumasını da bilirim dokumasını da" (s. 12)

\section{Erek metin}

"I know neither read nor weave" (s. 13)

Çevrilen cümleden 'ne okumasını bilirim ne dokumasını bilirim' anlamı çıkmaktadır ki bu kaynak metinde yer alan cümlenin tam tersidir.

Konuşma dili, resmi kullanımlar, günlük ifadeler, yöresel kültürel, edebî ifadeler uslûp ile ilgili faktörler içerisinde yer almaktadır. Eser bir tiyatro ürünü olduğu için diyaloglar, ünlem ifadeleri, edebi ifadeler içermektedir. Bu ifadelerin doğru aktarımı eserin bütünsel yapısı ve anlamını da etkilemektedir. Edebî ifadeler de uslûp ile ilgili unsurlardır. Eserin giriş anlamına gelen 'mukaddime' bölümü geleneksel olarak Karagöz Gölge oyununu başlangıcında yer alan perde gazeli ile başlamaktadır. Aruz vezni ile yazılmış olan gazel yazıldığı dönemde konuşulan dilleri yansıtmaktadır. Osmanlıca, Arapça ve Farsça kelimelerin yoğunlukta olduğu gazelin İngilizceye kelimesi kelimesine çevrildiği görülmektedir. Günümüz Türkçesi ile de anlaşılması güç olan kelimeler erek kültür için daha da anlaşılmaz hal almıştır. Sadece kelime ve cümle bağlamında yapılan çeviride aynı söz dizimi, uyak düzeni sağlanamamıştır ve edebî anlam erek dile aktarılamamıştır. Bu durumda öncelikle dil içi çevirisi gerekli olan gazelin erek dilde olmayan bir tür olması ve erek kültürde yer almayan kendine özgü yazım şeklinin olması etkili olmuştur. Dolayısıyla erek kültürde anlamsızlığa yol açan bu sorun gazelin kaynak metindeki şekliyle sunulması seçeneği ile çözülebilir. Günümüzde de yazılmış ve sahnelenmiş olan oyunlarda bu bölümün günümüz Türkçesine göre düzenlendiği, hatta dinleyici (çocuk, yetişkin) grubuna göre hazırlandığı bilinmektedir. Perde gazelinin Karagöz gölge oyunu açısından tasavvufî boyutu vardır. Perdeye yansıtılan bir hayâl kurgusudur ve pek çok şeyi semboliktir. Oyun bittiğinde figürler kaybolur. Sahne fani dünyanın bir aynasıdır. Oyun bittiğinde figürlerin perdeden silinmesi gibi hayat bittiğinde de insanlar hayat perdesinden silinmektedir. Bu anlamın erek kültürde sağlanabilmesi için bu bilginin erek metin okurları, dinleyicileri ve izleyicileri tarafından bilinmesi gerekmektedir. Eserde yer alan gazelin ilk iki dörtlüğünün İngilizce çevirisinden örnekler şu şekildedir:

\section{Örnek 15:}

\section{Kaynak metin}

Söyler erbab-ı fetanet perdeden / Gösterir Hikmet şinâsâna cihan-ı perdeden

Zevk ü șevkle yâdigar bir șem'a yakmış ehli dil / Sîretin surette bildirmiş nişân-ı perdeden

\section{Erek metin}

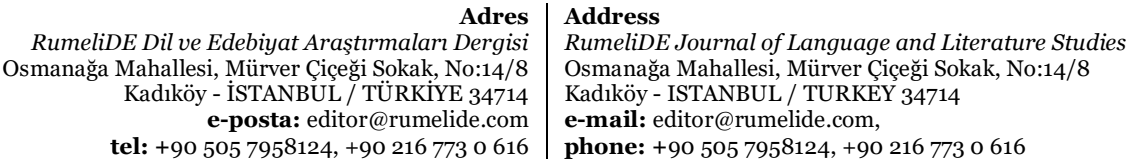

RumeliDE Dil ve Edebiyat Araştırmaları Dergis el: +90 $5057958124,+902167730616$ 
Says the expert of the resolution on the stage / Presents the wise universe on the stage

Has fired the speech master the remembrance candle / In a copy of a mood has the declared the sign of the stage

Hacivatın oyun başlamadan önce söylediği "Yar bana bir eğlence, yar bana bir eğlence" çağrısı da yine oyunun geleneksel özelliklerinden biridir. Belli bir makamda söylendiği için bu açılış cümlesinin erek metinde kaynak metindeki benzer etkiyi yaratması için seçilecek olan kelimelerin makama uyması ve söylenebilir olması gerekmektedir. Oyunun bitiminde de geleneksel olarak bir bitiş gazeli ve ritüeli vardır. Gazel ve bitiriş ritüeli şu şeklidedir:

\section{Örnek 16:}

\section{Kaynak metin}

"Ylktın perdeyi eyledin viran / Varayım sahibine haber vereyim heman"

\section{Erek metin}

"We pulled down the scene and made it ruinuous /Lets go and call its owner immidiately" (pg. 29)

\section{Örnek 17:}

\section{Kaynak metin}

"Her ne kadar sürç-i lisan ettikse affola"

\section{Erek metin}

"We wish you don't mind if we have slipped" (pg. 29) cümlesi ile karşılanmıştır.

\section{2. selected stories of Hacivat and Karagöz eserinin ilave dil ögeleri açısından incelenmesi}

Reiss'ın çeviri eleştirisi yaklaşımının ilave dil ögelerini anlık durum, konu alan bilgisi, zaman faktörü, yer faktörü, dinleyici ve izleyici faktörü, konuşmacı ve yazar faktörü, etki faktörü oluşturmaktadır. Tiyatro metinlerinin sahnelenmesi esnasında bazen oyun metninde yer almayan cümleler, kelimeler üretilebilmektedir ve bu doğaçlama olarak tanımlanmaktadır. Bu teknik Karagöz gölge oyununda da başvurulan bir tekniktir. Tulûat yani doğaçlama kabiliyet, tecrübe ve genel kültür gerektirir (Oral, 2019: 23). Oyunu erek dilde İngilizce olarak oynatan hâyali bu durumu göz önünde bulundurmalı, izleyici kitlesi ve tepkisine göre doğaçlama çeviri yaratımına hazırlıklı olmalıdır. Diğer bir dil dışı unsur ise çevirmenin veya çeviri eleştirmeninin çeviri metni konusu ve alanı ile ilgili bilgisi olmasıdır. Bunun için öncesinde iyi bir araştırma yapılmalı yapılan araştırmalar ışığında metin çözümlenmeli ve eleştirilmelidir. Zaman faktörü de çeviri ve çeviri eleştirisini etkileyen bir diğer unsurdur. Özellikle klasik Karagöz gölge oyunları metinleri eski döneme ait oldukları için Arapça, Farsça ve Osmanlıca gibi o dönemde konuşulan dili yansıtmaktadır. Çeviride zorluk yaratan bu durum öncelikle dil içi çeviri gerektirmektedir. Kelimelerin anlamları ve dönemsel kullanımları hakkında bilgi edinilmelidir. İncelenen İngilizce eserde Arapça, Farsça ve Osmanlıca birçok kelimenin yer aldığı görülmektedir. Hatta oyunun mizahî çatısını oluşturan kelime oyunlarında

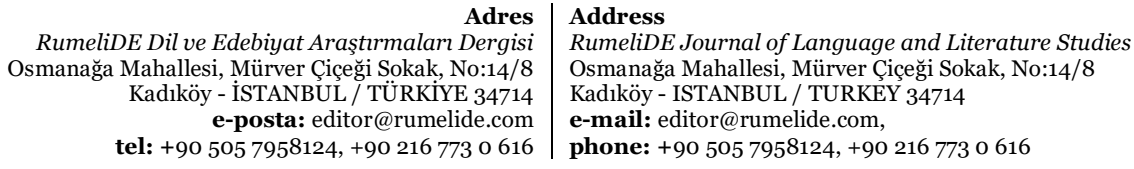


sıklıkla bu yabancı kökenli kelimelerin yer aldığı gözlemlenmiştir. Bu bağlamda kelimelerin anlamlarının metnin bağlamı içerisinde değerlendirilmesi gerekmektedir. Çeviri örneklerinde metinde yer alan kelime ve ifadelerin zaman zaman bağlamdan bağımsız olarak kelime ve cümle olarak çevrildiği belirlenmiştir.

Özellikle eski oyun metinlerinde etkilerinin daha fazla görüldüğü yer faktörü oyunda yer alan tiplerin diyaloglarında etkili olmuştur ve karakter yoluyla İstanbul'un her kesiminden insan manzaraları örf ve âdetlerle birlikte sunulmuştur. Geçmişte saray, konak, kahvehane, meydanlar gibi farklı mekanlarda icra edilmiş olan Karagöz gölge oyunu günümüzde de eğitim programı kapsamında okul etkinliklerinde, ramazan programlarında oynatılmaktadır. İzleyici faktörü çeviri ve çeviri eleştirisi açısından göz ardı edilmemesi gereken unsurlardan biridir. Örneğin oyunun sergileneceği izleyici kitlesi küçük yaş grubu ise seçilen kelimeler yaş grubunun anlayacağı seviyede olmalıdır. Faklı bir kültür için çevriliyor ise o kültür için anlaşılması güç öğeler gözden geçirilmelidir. Yazılan metinlerin çevirilerinde de bu husus göz önünde bulundurulmalıdır. Yazar ve konuşmacı faktörü çeviri metinlerini etkilemektedir. Kaynak metinde yer alan karakterlerin konuşmaları kendilerine özgü özellikleri korunarak erek kültüre aktarılmalıdır. Karagöz eğitim görmüş Hacivat'ın konuşmasını sürekli yanlış anlayan cahil bir kişi konumundadır. İkinci tipler olan Çelebi, Beberuhi, Tiryaki, Tuzsuz Deli Bekir, Zenne, Arap, Arnavut, Çerkez gibi karakterlerin her birinin kendine özgü konuşma tarzı ve ifadeleri vardır. İncelenen çeviri eserde kaynak metinde yer alan bazı karakterlerin söylemlerine karakteristik özelliklerinin yansıtılamadığı belirlenmiştir. Örneğin Tuzsuz Deli Bekir kabadayı, sinirli, kaba bir tiptir. Kaynak metinde yer alan "Yahu söylesene adın ne senin?" (s. 20) ifadesi İngilizceye “Well, please tell me your name?” şeklinde aktarılmıştır. Bu aktarım karakterin özelliğini yansıtmamaktadır ve sahnelenebilirlik açısından da oyunun doğallığını ve inandırıcılığını olumsuz yönde etkilemektedir. Benzer durum Karagözün "Yes please, ask. I will find that one” ifadesinde de görülmektedir. Karagöz, patavatsız, sabırsız, aceleci, kibar konuşmayı pek bilmeyen bir tiptir ve bu cümle onun söylem tarzına pek uymayan bir cümledir. Çeviride geçen şiveler erek metne aktarılamamıştır. Karadenizli 'nin "Burası ne güzel bir lokantadır da" ifadesi, Kayserili'nin “Vay bu ne gozel dükkanmış bole”, ifadelerinin düz cümleler olarak çevrildiği görülmektedir (s. 23) Etki faktörü çeviri eleştirisinin son aşamasında değerlendirilen öğelerin erek dilde yarattığı sonucun ne olduğunu, kaynak metnin ne derece erek metne yansıtılabildiğini, aynı veya benzer etkiyi sağlayıp sağlayamadığını irdeleyen noktadır. Bu kapsamda kaynak metinde yer alan, mizahın, hicvin, mecazi anlatımın, vurgunun erek metinde ne derece sağlanabildiği saptanır. Karagöz gölge oyunun mizahı yapısını Karagözün, Hacivat'ın söylediklerini konuyla ilgili bilgisi olmaması sebebiyle yanlış anlaması ve ses benzerliği kurduğu kelimelerle cevap vermesi oluşturmaktadır. $\mathrm{Bu}$ kelimelerdeki ses benzerliği olayının farklı dil özellikleri ve kelime yapılarına sahip diller arasında sağlanması zor olduğu için erek metinde mizahı sağlayacak şekilde yeniden üretilmesi gerekmektedir. İncelenen kaynak metinde bu yolla sağlanan kelime oyunları ve mizah, çeviri metinde kelimelerin sadece dildeki karşılıkları çevrildiği için sağlanamamıştır ve dolayısıyla Karagöz oyununa özgü mizah unsurları da kaybolmuştur. Aşağıda bu durumu doğrulayan çeviri örnekleri sunulmuştur:

\section{Örnek 18:}

\section{Kaynak metin}

"Vay, Karagözüm sen mürekkep yaladın mı?” (s. 12)

“Bizim Komşunun merkebi vardı, pek sevdim yaladım” (s. 12)

\section{Erek metin}

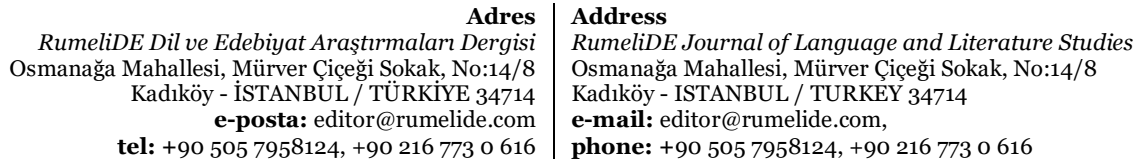
tel: +90 $5057958124,+902167730616$ 
"Oo Karagöz, have you got the test of the ink ?" (pg. 13)

"My neigbour had a donkey. I liked it very much and kissed him once" (pg. 13)

Erek metinde kaynak metindeki diyalogda olduğu gibi ses benzerliğiyle sağlanan mizahi unsur yer almamaktadır.

\section{Örnek 19:}

\section{Kaynak metin}

"Așçıya çırak olacaksın" (s.16)

"Şuradan buradan mal mı aşıracağım? (s.16)

\section{Erek metin}

"You will be apprentice to a cook" (s. 16)

"What? Will I steal good? (s. 16)

Bu örnekte ses benzerliği yoluyla mizah sağlanmış görünmektedir.

\section{Örnek 20:}

\section{Kaynak metin}

"Taranmaya değil yaranmaya çağırdım” (s. 17)

\section{Erek metin}

“I don't want you to comb yourself but ingratiate yourself (pg.17).

Erek metinde yer alan kelimeler arasında kaynak metindeki kelimeler arsında yer alan ses benzerliği olmadığı için kaynak metindeki mizah unsuru erek metne yansıtılamamıştır. Dolayısıyla aynı etki sağlanamamıștır.

Reiss'ın yaklaşımına göre nesnel bir çeviri eleştirisi sağlanabilmesi için öncelikle metin türünün belirlenmesi ve o metin türünün özelliklerinin iyi bilinmesi gerekmektedir. Çünkü çeviri veya çeviri eleştirisi ile ilgili alınacak olan kararları öncelikle metin türü belirleyecektir. Daha sonraki bir işlem olarak metin dil içi öğeler ve dil dışı öğeler ve içerdikleri unsurlar bağlamında incelenmeli ve değerlendirilmelidir. Değerlendirme sonucunda tespit edilen sorunlar için öneriler sunulabilir. Reiss'a göre bir çeviri eleştirisi sadece eleştirmeyi amaçlamamalı, yapıcı olmalıdır. Bu kapsamda yapılan inceleme sonucunda çeviri eserde karşılaşılan en büyük problemin diller ve kültürlerarası farlılıklar sebebiyle Karagöz oyununun mizansenini oluşturan kelime benzerliklerinin, kelime oyunlarının erek kültüre aktarılamaması ve kaynak metindeki güldürü etkisinin yaratılamamasıdır. Kelimelerin birebir çevirisi ile sağlanması mümkün olmayan bu etki için yeni yaratımlara ihtiyaç vardır. Çevirmen verilen anlamı yorumlayan olduğu gibi anlamın aktarılamadığı durumda anlam yaratıcısı olabilir.

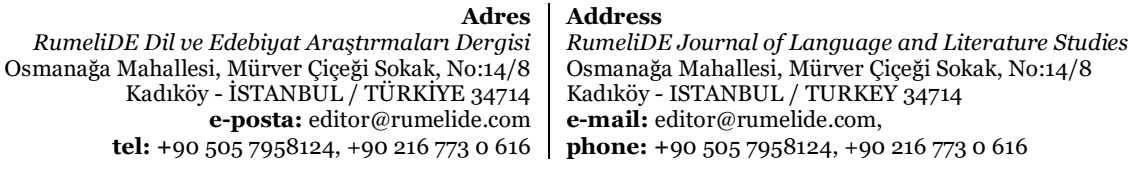




\section{Karagöz oyunlarında yenileştirme çalışmaları}

'Muhavere' Karagöz ve Ortaoyununda kullanılan bir terimdir. Fasıl bölümüne geçmeden önce yapılan diyalog kısmıdır. Bu bölüm fasıl bölümünden bağımsızdır. Bu bölümde geçen konuşmalar herhangi bir konu ile ilgili olabilir. Oral'ın (2019:10) vermiş olduğu bilgilere göre istenirse bir muhaverenin başına "giriş" sonuna da "bitiş" bölümü eklenerek ve dans, müzik, şiir gibi unsurlarla süslenerek yeni birçok oyun yazılabilir. Bu bağlamda geçmişten günümüze ulaşmış sahnelenmeye devam edilen birçok muhâvere vardır (a.g.e.: 10). Muhâvere yazımları Karagöz gölge oyunu geleneğinin yaşatılmasına büyük katkı sunmaktadır. Hayâli oyun metnini ve muhavereyi de yazabilir. Anacak muhâvere yazımı Karagöz gölge oyunu uslûbunu bilmeyi, yazılacak olan dilin kültürüne hâkim olmayı, dolayısıyla eşanlamlı ve eşsesli kelimeler, bilmece ve atasözü gibi dile özgü yapıları bilmeyi, tulûat tekniğini uygulayabilmeyi gerektirir. Temal amaç güldürmektir (a.g.e.: 10). Muhâvere yazımı için yeniden yazım, yeniden yaratım da denilebilir.

Zaman içinde bazı yasaklamalara maruz kalan ve sadece ramazan ayı etkinlikleriyle sınırlı kalmaya başlayan gölge oyunumuz Karagöz için bir takım yenileștirme çalışmaları yapılmaya başlanmıştır. Efsanelerden, halk hikâyelerinden, edebî eserlerden faydalanılmış ve değişik uyarlama oyunlar ortaya koyulmuştur. Leyla ile Mecnun, Tahir ile Zümre, Ferhat ile Şirin bu oyunlardan bir kaçıdır. Metin Özlen tarafından metni yeniden kurulan Leyla ile Mecnun önce Metin And (1985) daha sonra İvgin-Özlen (1996) ikilisi tarafından yayımlanmıştır (Sakaoğlu, 2011: 81). Bunların yanı sıra gerçekçi İstanbul hikâyelerine dayandırılan Tayyârzade Hikâyesi (1994), Hain Kâhya, Cevri Çelebi gibi metinler de yazılmış, fakat Hain Kâhya hariç diğer oyunların metinleri günümüze gelememiştir (Sakaoğlu, 2011: 83). Romanlardan ve tiyatro eserlerinden de uyarlamalar yapılmıștır. Romandan uyarlanan Karagöz oyunun ilk örneği Hâyali, Küçük Ali (Muhittin Sevilen)'in ve Ahmet Mithat Efendi'nin Hasan Mellah Hüseyin Fellah adlı romanından uyarladığı oyundur (a.g.e.: 83). Ayrıca Ahmet Mithat Efendi Karagözcü "Kâtip Salih" ile perdede buzlu cam, Karagöz suretlerinin büyütülmesi, perde üzerinde ev, dekor, oyun öncesinde saz çaldırmak, mum yerine elektirik kullanmak gibi yenileştirme hareketlerinin öncüsü olmuşlardır. (Mutlu, 1995 :62). Sakaoğlu (a.g.e.: 84)'nun sunmuş olduğu bilgilere göre Fransız tiyatro tarihçilerinden Adolphe Thalasso bir yazısında Moliére'in üç oyununun bazı bölümlerinden faydalanılarak üç Karagöz faslının ortaya konulduğunu bildirmiştir. Bunlardan birisi "Cimri" oyununun birinci perdesinin üçüncü sahnesi, "Tartuffe" oyununun birinci perdesinin beşinci sahnesi, "Scapin'in dolapları" oyununun ikinci perdesinin ikinci sahnesidir. "Scapin Dolapları" oyununun Direktör Ali Bey tarafından yapılmış adaptesi 'Ayyar Hamza' adını taşımaktadır. Aynı yazarın 'Zoraki Takip' adlı tiyatro eseri de Hayâli Küçük Ali tarafından uyarlanmıştır. Bunlara ek olarak Doğu Edebiyatı ve kültürüne dayandırılan (Binbir Gece Masalları gibi) oyunlar da olmuştur.

Cevdet Kudret Karagöz oyunlarını Kâr-ı Kadîm (eski zaman işi, klasik) ve Nev-icâd (yeni uydurulmuş modern) olmak üzere iki gruba ayırmıştır (Kudret, 1969: 24). And (1969:248) ise Karagöz oyunlarını, en eski oyunlar, Meşrutiyet çağının oyunları, Cumhuriyetten sonraki oyunlar olmak üzere üç grupta incelemiştir. Kâr-Kadim oyunları içerisinde İmparatorluk dönemi oyunları, Nev-i İcâd dönemi oyunları içerisinde Meşrutiyet dönemi oyunları yer almıştır ve bu dönemde oynanan oyunlarda yenilikler başlamış, eski oyunların isimlerinde, dekor ve tiplemelerinde güncellemeler yapılmıştır. Salih Efendi, Behiç Efendi, Memduh Bey gibi hâyaliler klasik oyunların yanı sıra Karagöz'ün başka ülkeleri gezdiği, yeni oyunlar da kaleme almış ve oynatmışlardır. Cumhuriyet döneminde ise yenileștirme hareketleri devam etmiştir, Hayâli Memduh, Mehmet Muhittin Sevilen (Hayalî Küçük Ali), Ahmet Süleyman, K. M Vasıf Okçugil, İsmail Baltacıoğlu, Mustafa Rahmi Balaban, Ercüment Behzat Lav, Abdülkadir Karamürsel, Mustafa Rona, Nejat Akdemir, M. Ünver Oral, Nurhan Şener, Aziz Nesin, Tekin Özerten gibi isimler yeni oyunların yazımı sergilenmesine katkı sunmuşlardır (Sakaoğlu, 2011: 101-106). Nevzat Açıkgöz'ün oğlu Camcı İrfan

\footnotetext{
RumeliDE Dil ve Edebiyat Araştırmaları Dergisi Osmanağa Mahallesi, Mürver Çiçeği Sokak, No:14/8 Kadıköy - ÍSTANBUL / TÜRKIYE 34714 e-posta: editor@rumelide.com tel: +90 $5057958124,+902167730616$

Address

RumeliDE Journal of Language and Literature Studies

Osmanağa Mahallesi, Mürver Çiçeği Sokak, No:14/8

Kadıköy - ISTANBUL / TURKEY 34714

e-mail: editor@rumelide.com,

phone: +90 505 7958124, +90 2167730616
} 
Açıkgözden sanatı öğrenmiş olan gölge oyunu ve kukla ustası Tacettin Diker kırk yıl boyunca Akbank Karagöz ve Kukla Tiyatrosunu yönetmiş, yurtiçi ve yurt dışında çeşitli festivaller ve kongrelerde konuklara temsiller vermiştir. Günümüz olaylarını yeni tiplerle sahnelemiştir (Tan, 2014: 219-221). Açıkgöz, Diker gibi birçok ustanın yetiştirdiği Hayâliler de oyunlar yazmış sergilemiş ve bu sanatı genç nesle aktarmaya çalışmışlardır. Yeniliklerin devam ettirilmesi kapsamında çeşitli Karagöz oyunları metin yarışmaları da düzenlenmiş, Karagöz repertuarına yeni oyunlar kazandırılmıștır.

\subsection{Gölge oyunu Karagöz ve transceration kavramı}

Transcreation hem yaratım hem çeviri olmak üzere iki kelimeden oluşmaktadır. Çeviri yaratım, yaratıcı metin uyarlaması gibi kavramalarla da dönüşümlü olarak kullanılmaktadır. Günümüzde daha çok reklam alanındaki çeviri çalışmaları ile anılan bir terim halini almışsa da transcreation ile ilgili ilk çalışmalar yazın çevirileri üzerinde olmuştur. İlk olarak 1957 yllında Else Vieria tarafından drama çevirilerinin zenginliğini arttırmak için kullanılmıştır (Gaballo, 2012:97) Hindistan'da ise terim kutsal metin çevirileri için kullanılmış, sadık olmayan okunabilir çeviri türünü sembolize etmiştir (Pedersen, 2014: 58). "De Campos" terimi 'transcreation' kavramını bir edebi metinin 'yeniden icadı' olarak değerlendirmektedir (a.g.e.: 97). $\mathrm{Bu}$ çeviri tekniğinde çevirmenden yaratıcı olması ve eşdeğerliğin sağlanmasının zor olduğu durumlarda fikir üretmesi beklenir. Amaç, kaynak metindeki aynı havayı erek kültürde de yaratabilmek ve aynı etkiyi sağlayabilmektir. Bu tiyatro çevirileri için de çok önemlidir. Bir dilde güldürücü olan bir şey başka bir dilde anlamsız olabilir. Bu sebeple amaç öncelikle kaynak kültürdeki havayı başka bir kültürde yaratabilmek ve erek kültürde kaynak kültürdeki benzer etkiyi sağlayabilmek olmalıdır. Bu bağlamda bazı çalışmalar yapılmıştır. Yazılan yeni oyunlar yeni yaratımlar çevirileri ile dünya tanıtımına çıkmıştır. İngiltere'de yaşayan Mengü Türk Yunus Emre Enstitüsü tarafından Türk kültürünü tanıtma kapsamında Karagöz müzesinin 'Salıncak' isimli oyununun İngilizce çevirisi İngiliz çocuklarla buluşturulmuştur. Oyunun finalinde yer alan Barış Manço şarkısının Michael Jackson'ın şarkısı ile değiştirilebileceği, İngiliz kültürüne yakın espri ve motiflerle oyunun İngiliz çocuklara tanıtılıp sevdirilebileceği ifade edilmiştir. Bursa'da gerçekleştirilen "Dünya Tarihi Kentler Birliği” nin toplantısında Karagöz Sanatçısı Osman Ezgi tarafından Karagöz Oyunu İngilizce sahnelenmiştir. Oyunda İngilizce tekerlemelere yer verildiği, perde gazeline İngilizce sözler uyarlandığı görülmektedir. Türkçe 'de yer alan bazı ifadelerin de doğaçlama kullanıldığı oyunda bir kültür mozaiği oluşturulmuştur. Oyun görüntülerinin sonunda yer alan röportajda Ezgi, yurtdışında daha önce de İngilizce yazılmış oyunlar sergilediklerini ve kültür farklılığı sebebiyle her milletin farklı mizah anlayışı olduğunu ifade etmiştir ve mizahın kaybolmaması için oyunu yazan çevirmenin ve sahneleyen hayâlinin dili iyi bilmesi gerektiğinin altını çizmiștir (https://www.dailymotion.com/video/x6t8wwd, 22.062021).

Bir başka Hayâli sanatçısı Ayhan Hulagu da kendi yazmış olduğu metinleri Amerika'da sergilemiştir. Bu çalışmalardan birisi de Modern Karagöz Show adıyla Shakespeare'in Hamlet eserinden oyunu "Dream of Hamlet'dir. (https://karagoztheatre.com/about/, 21.06.2021). Ali Köken de başta Almanya olmak üzere birçok ülkede Karagöz oyunu sahnelemiş bir hayâlidir. Köken, Almanya'da birçok Karagöz oyunu sergilendiğini, fakat Türkçe sergilenen oyunların çok beğenilmesine rağmen Almanların merakını tam olarak gideremediğini ifade etmektedir. Bu sebeple Köken, "Karagöz Almanya'da" adlı oyun ve daha sonrasında da Almanca oyunlar yazmıştır. Avusturya ve İsviçre'de de Almanca, Türkçe gösteriler sunmuştur (Köken, 2020: 10-12).

Işık Soytürk (2001: 7-11) tarafından hazırlanan “Karagöz ve Hacivat kitabında” Ünver Oral'ın "Çocuklara Karagöz Hikâyeleri" kitabında yer alan trafik kuralları nuhaveresinden (söyleşme) alınmış, genişletilerek yeniden kurgulanmış, Yelda Diker ve Andrea Dillon Körner tarafından İngilizceye, Mete Soytürk ve Mechtild

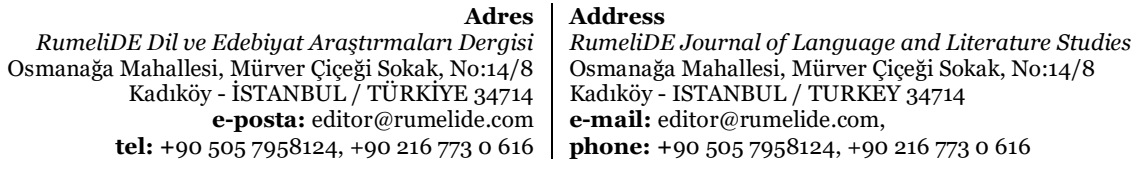


Kohl Soytürk tarafından Almancaya çevrilmiştir. Hacivatın söylediklerini yanlış anlayan Karagöz'ün benzerlik yoluyla ürettiği komik sözcüklerdeki mizahi etki çeviri metinde erek dilde yer alan benzer işleve sahip kelimeler üretilerek sağlanmıştır. Böylece güldürme amacı yerine getirilmiştir. Çeviri metinde yer alan örneklerden bazıları şöyledir:

\section{Örnek 21:}

\section{Kaynak metin:}

Hacivat: Karagözüm nedir bu gürültü neler oluyor?

Karagöz: Bu sıcak havada çiçekler soluyor (Soytürk, 2001: 4).

\section{Erek metin:}

Hacivat: Hello, my dear Karagöz! Come here?

Karagöz: What do you “Can you hear"! Of course I can hear ! (Soytürk, 2001: 7).

\section{Örnek 22:}

\section{Kaynak metin:}

Hacivat: Sana soranda kabahat bak trafik tıkanmıs

Karagöz: Göremedim hangi patik yıkanmış?

Hacivat: Patik değil trafik (Soytürk, 2001: 4).

\section{Erek metin}

Hacivat: Oh, never mind. Look, what a mess. There is a traffic Jam.

Karagöz: Oh, I like Jam on my toast for breakfast

Hacivat: I am not talking about breakfast Jam. I am talking about a traffic Jam (Soytürk, 2001: 7-8).

\section{Örnek 23:}

\section{Kaynak metin}

Hacivat: ...Şimdi ilerdeki kavşağa dikkat et.

Karagöz: Hay hay yerdeki kuşağa dikkat ederim. Kimseye çaldırmam (Soytürk, 2001: 4)

\section{Erek metin:}

Hacivat: For example keep an eye on the crossing point over there.

Karagöz: Oh, don't worry. I will keep an eye on that croissant. Don't worry! (Soytürk, 2001: 7).

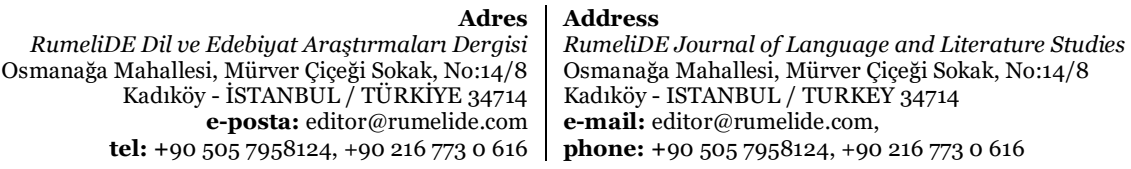




\section{Örnek 24:}

\section{Kaynak metin}

Hacivat: Kuşak değil, kavşak! Yani dört caddenin kesiştiği bir meydan. İyi bak orada ne var?

Karagöz: Ne var ne var yerde bir kürdan var

Hacivat: Pekiyi meydanın ortasında ne var?

Karagöz: Bir sürü araba var Hacı Cavcav en çok da gürültü var (Soytürk, 2001: 4)

\section{Erek metin:}

Hacivat: My dearest friend! Not croissant! Croosing point! It means that four streets intersect in a square. Now look over there. What do you see at the intersection!

Karagöz: What is it? What is it? I see many insects down there.

Hacivat: You clever boy! Not insects! What do you see at the intersection in the middle of the square (Soytürk, 2001: 7)

\section{Örnek 25:}

\section{Kaynak metin}

Karagöz: (İçinden: "Sola sağa, sola, sava, ışık, kaşık diye bu adam benim başımı döndürecek yahu. Sen iyisi mi bunları boşver" Kaşık yoksa kepçe buluruz be arkadaşım (Soytürk, 2001: 5).

\section{Erek metin}

Karagöz: (Murmuring again: Left, right, left, right, delight...This boy is confusing me). Let's forget everything. If there is no delight, let's enjoy the sunlight (Soytürk, 2001: 8).

Örneklerde kaynak metindeki mizahi etkinin erek metinde sağlanabilmesi için metin içi uyarlamalar yapıldığı, kaynak metnin erek metnin kültürüne göre kurgulandığı ve yazarın amacı ve metnin bağlamına sadık kalınarak yeni bir çeviri ürün ortaya konulduğu görülmektedir. Türk gölge oyunu Karagöz'ün sürekliliğini sağlamak ve başka kültürlere tanıtmak, eklenen yeni tipler, motifler ve kültürel değerlerle birlikte kültürlerarası iletişimi sağlamak için yapılan bu çalışmalar kültürel mirasın gelecek nesillere aktarılmasına büyük katkı sağlamıştır ve yeni çalışmalarla sağlamaya devam edecektir. Çevirileri yoluyla yeniden üretilen, yazılan oyunlar Karagöz gölge oyununa olan ilgiyi arttırmıștır.

\section{Sonuç, değerlendirme ve öneriler}

Tiyatro çevirisi sadece kelimelerin anlamının çevrilmesi değil konuşulabilir, sahnelenebilir ve farklı kültürler tarafından anlaşılabilir bir ürün ortaya konmasını gerektirir. Reiss'ın yaklaşımına göre metin türünün gerektirdiği çeviri stratejilerinin iyi anlaşılması gerekmektedir. Metin türünün belirlenmesinden sonraki adım çeviri metninin dil içi ve dil dışı unsurlarıyla birlikte değerlendirilmesidir. Bu bağlamda Reiss, kapsamlı bir çeviri eleştirisi modeli sunmuştur. Bu modele göre dikkate alınması gereken en önemli

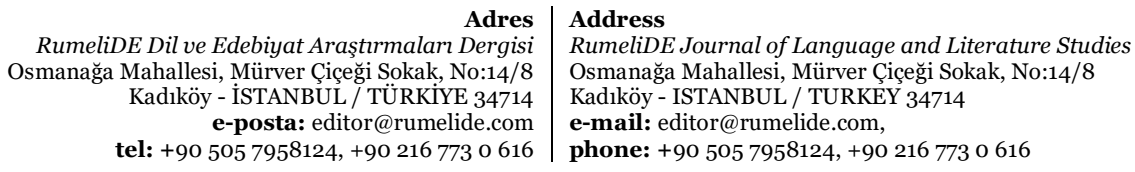


hususlardan birisi de yapılan çevirinin hangi amaçla yapıldığının bilinmesi ve işlevini yerine getirip getirmediğinin test edilmesidir. Reiss'ın dil dışı öğeleri arasında yer alan 'etki faktörü', çevirinin erek kültürde, kaynak kültürdeki etkiyi yaratması şeklinde tanımlanmaktadır. Bu noktada Reiss sadece dilsel göstergelerin ölçüt alınarak bu etkinin yaratılamayacağını göstermektedir. Çalışmada geleneksel tiyatromuzun önemli bir parçası olan gölge oyunu Karagöz konusu ele alınmış ve bu doğrultuda "Seçme Hikâyeler Hacivat ve Karagöz" eserinin İngilizce çevirisi Reiss'ın çeviri eleştirisi yaklaşımı kapsamında incelenmiştir. İnceleme sonucunda çeviri metninde tiyatro türüne uygun çeviri stratejilerinin yeterince uygulanamadığı görülmüştür. Diyaloglarda yer alan cümleler konuşma ifadelerinden çok yazın metni ifadeleri içermektedir. Dil içi öğeler açısından değerlendirildiğinde bazı kelime seçimlerinin erek kültürdeki kullanımlara uygun olmadığı, bu durumun da yanlış anlama yol açtığı görülmüştür. Eserde sözcüğü sözcüğüne çeviri yaklaşımının tercih edilmesi Karagöz oyununda sıklıkla kullanılan deyim, kelime oyunları, bilmece ve tekerleme gibi kültürel unsurların yeterince aktarılamamasına ve erek kültürde yer almayan bu öğelerin çevirilerinin anlam karmaşasına yol açtığı gözlemlenmiştir. Bilmece ve tekerlemelerin en önemli özelliği olan kafiyenin erek kültürde sağlanamadığı belirlenmiștir. Karagöz oyununun mizahi yapısını oluşturan, Karagöz'ün Hacivat'ın söylediği kelimeleri yanlış anlaması neticesinde ortaya çıkan kelime oyunları erek kültüre yansıtılamamıştır. Kelimeler arasındaki ses benzerlikleri neticesinde ortaya çıkan bu mizahi öğeler ancak erek dilde yer alan benzer yapıdaki kelimelerle oluşturulabilir. Bu durum çevirmenin yaratıcı olmasını ve erek kültürde aynı mizahi etkiyi yaratacak kelimeler üretmesini gerektirmektedir. Reiss'ın dil dışı öğeler kapsamında ele aldığı anlık durum faktörü Karagöz gölge oyunun sahnelenmesi sürecinde de karşılaşılan bir durumdur. Karagöz gölge oyunu tamamen metne dayalı oyunlar değildir. İzleyecinin tepkisi, yaş gurubu, ilgisi gibi faktörlere bağlı olarak sözlü çeviri işini üstlenen hâyalinin anlık durumlar, tipler ve espriler üretmesini gerektirebilir. Transcreation yani yaratım ve çeviri aynı anda gerçekleşir. Bu geleneksel tiyatroda Tûluat tekniği ile karşılanır. Bunu yapabilmek için hayâlinin alan ve terminoloji ile ilgili bilgisinin olması ve kaynak ve erek dilin kültürüne hâkim olması gerekmektedir. İncelenen eserde oyunun geleneksel özelliklerinin korunduğu, fakat bunun erek metne aktarımında bazı sorunlarla karşılaşıldığı anlaşılmaktadır. Bazı örneklerde karakterlerin söylemlerinin erek kültüre aktarımında karakteristik özelliklerinin yansıtılamadığı görülmektedir. Karagöz oyununun nev-i icâd (yeni uydurulmuş modern) döneminden günümüze kadar olan süreci ele alındığında çeşitli konularda birçok muhavereler yazıldığı, uyarlamalar yapıldığı ve oyunların faklı kültürlere tanıtımı sürecinde çeviri yaratımlar yoluyla sahnelendiği görülmektedir. Geleneksel oyunumuzun sevdirilmesi, yaygınlaştırılması ve tanıtılmasına katkı sunan bu yaratımların aynı zamanda dilsel farklılıklardan kaynaklı aktarım zorlukları için de yararlı olabileceği görülmüştür. Özellikle mizahi öğelerin kaynak kültürde yarattı̆̆ı etkiyi erek kültürde sağlamak zordur. Öncelikle çevirmen çevireceği metin türünün bilincinde olmalı, o türün kaynak kültürdeki konumu, kullanımı ve içeriği ile ilgili derin bilgi sahibi olmalıdır. Çünkü çeviri stratejisini metnin türü belirleyecektir. Tiyatro çevirilerinde sahnelenebilirlik, izleyici faktörü gibi unsurlar da göz önünde bulundurulmalıdır. Çevirmenin metni çevirmeden önce oyunu izlemesi, çevirmiş olduğu metni sesli olarak okuması yararlı olabilir. Yapılan bu çalışmanın ve çeviri eleştirisi kapsamında sunulan bilgi ve örneklerin çevirmen ve çevirmen adaylarına ışık tutacağı, alana katkı sağlayacağı düşünülmüştür.

\section{Kaynakça}

Anamur, H. (2000). Beș Düzeyli Nesnel Çeviri Yöntemi ve Uygulama Örnekleri: Çeviri Eleștirisi, Ankara Üniversitesi Tömer Bursa Şubesi: 121-130.

And, M. (2004). Başlangıcından 1983'e Türk Tiyatro Tarihi. İletişim.

Aykaç, O. (2016). Karagöz ve Hacivat: Başkaldırı ve Itaatin Yansımaları. SEFAD. (36), 611-618.

Gaballo, V. (2012). Exploring The Boundaries of Transcreation in Specialized Translation. ESP Across Cultures 9.

Adres | Address

RumeliDE Dil ve Edebiyat Araşturmaları Dergisi Osmanağa Mahallesi, Mürver Çiçeği Sokak, No:14/8 Kadıköy - ISTANBUL / TÜRKIYE 34714 e-posta: editor@rumelide.com tel: +90 $5057958124,+902167730616$

RumeliDE Journal of Language and Literature Studies Osmanağa Mahallesi, Mürver Çiçeği Sokak, No:14/8

Kadıköy - ISTANBUL / TURKEY 34714

e-mail: editor@rumelide.com,

phone: +90 5057958124, +90 2167730616 
Gerçek, S. N. (1942). Türk Temaşası / Meddah Karagöz Orta Oyunu. İstanbul.

Gökcan, M. (2016). Küşteri Meydanında Zaman Yolculuğu Geçmişten Günümüze Karagöz Oyunlarının Toplumsal Boyutu. Erzincan Üniversitesi Sosyal Bilimler Enstitüsü Dergisi. ÖS. III:83-92.

Haleva, B. (2001). Orhan Veli Kanık'ın Şiir ve Tiyatro Çevirilerinin Kuramsal Açıdan İncelenmesi. Yıldız Teknik Üniversitesi Sosyal Bilimler Üniversitesi. YLT.

Haleva, B. (2011). Tiyatro Çeviri Bağlamında Bernard- Marie Koltes Oyunlarının Türkiye'deki Dolaşımı, Doktora Tezi

Hınçer, İ. (1959). Gölge Oyunlarının ve Karagöz'ün Doğuşu. Türk Folklor Araştırmaları Dergisi, 5 (119), s.1931-1932.

Jacob, G. (1925). Geschicte des Schattenheaters im Morgen und Abendland, Hanniver.

Koller, W. (1997). Einführung in the Übersetsungswissenscahft Weisbaden: Francke Verlag.

Kudret, C. (1969). Karagöz. Cilt I. Bilgi.

Kutlay, Y. S. (2020). Çeviribilimde Çeviriyaratımı Konumlandırmak. RumeliDE Journal of Language and Literature Studies. 18 (March): 688-698). DOI: 10.29000/rumelide.706483

Maral, N. (2010). Tiyatro Metin Çevirilerinde Çeviri Sorunları. Dokuz Eylül Üniversitesi Sosyal Bilimler Enstitüsü. Yüksek Lisans Tezi.

Munday, J. (2001). Introducing Translation Studies. Theories and Applications. Routledge.

Mutlu, M. (1995). Karagöz. Tiyatro Araștırmaları Dergisi. 12(12), 53-63. https://doi.org/10.1501/TAD_0000000197

Martin, M. M. (2020). Transcreation as a Way to Promote Employability in Translation Training: Adding Value to Translation Training. Hermes- Journal of Language and Communication in Business no: 60: 125-139.

Oral, Ü. (2009). Turkish Shadow Play Karagöz. Republic of Turkey Ministry of Culture and Tourism.

Oral, Ü. (2019). Karagöz-Hacivat Muhavereleri. Kitabevi.

Öztürk, S. (2006). Co-Opted: Turkish Shadow Theatre of The Early Republic (1923-1945). Asian Theatre Journal. 23(2): 292-313. doi: 10.1353/atj.2006.0027

Pedersen, D. (2014). Exploring the Concept of Transcreation-transcreation as 'more than translatşon'? Cultus: The Journal of Intercultural Mediation and Communication. Volume 7: 57-71.

Reiss, K. (2014). Translation Criticism: The Potentials and Limitations. (Translated. Erroll F. Rhodes). Routledge.

Sakaoğlu, S. (2011). Türk Gölge Oyunu Karagöz. Akçağ.

Soytürk, I. (1999). Anadolu Binbir Renk: Karagöz ve Hacivat. (Çev. Yelda Diker \&Andrea Dillon-Körner). Filiz.

Tietze, A. (1977). The Turkish Shadow Theatre and Puppet Collection of the L. A. Mayer Memorial Foundation. Berlin Gebr. Mann Verlag.

Türkyılmaz, D. (2013). Karagözü Yeniden Hayata Katmak Üzerine Bazı Öneriler. Gazi Türkiyat Bahar. 12: 51-58.

Üstün, Z. (2007). Seçme Hikâyeler Hacivat ve Karagöz. Profil.

Üstün, Z. (2007). Selected Stories of Hacivat and Karagöz. (Çev. Havva Aslan). Profil.

Yılmaz, F. \& Taşkın, M. (2014). Hacivat Karagöz Oyunları ile Türkçe’nin Yabancı Dil Olarak Öğretimi ve Kültür Aktarımı. Akademik Sosyal Araştırmalar Dergisi. Yıl:2 Sayı: 5: 270-288.

Zeytinkaya, D. (2018). Tiyatro Çevirisi Sürecinde Karşılaşılan Sorunlar ve Çözüm Önerileri. Uluslararası Sosyal Araştırmalar Dergisi. 11(59).

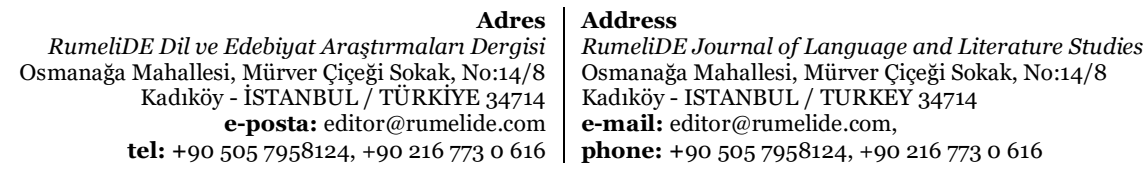


574 / RumeliDE Journal of Language and Literature Studies 2021.S9 (August)

A study on the English translation work Selected Stories of Hacivat and Karagöz / B. Yaman (pp. 552-574)

Adres Address

RumeliDE Dil ve Edebiyat Araştırmalar Dergisi $\quad$ RumeliDE Journal of Language and Literature Studies Osmanağa Mahallesi, Mürver Çiçeği Sokak, No:14/8 Osmanağa Mahallesi, Mürver Çiçeği Sokak, No:14/8 Kadıköy - ISTANBUL / TÜRKIYE 34714 Kadıköy - ISTANBUL / TURKEY 34714

e-posta: editor@rumelide.com e-mail: editor@rumelide.com,

tel: +90 505 7958124, +90 2167730616 phone: +90 505 7958124, +90 2167730616 